\title{
MEDIATION OF ENDOEVAPORITIC MICROBIAL COMMUNITIES IN EARLY REPLACEMENT OF GYPSUM BY DOLOMITE: A CASE STUDY FROM MIOCENE LAKE DEPOSITS OF THE MADRID BASIN, SPAIN
}

\author{
M. ESTHER SANZ-MONTERO, ${ }^{1}$ J. PABLO RODRÍGUEZ-ARANDA, ${ }^{1}$ AND J. PEDRO CALVO ${ }^{2}$ \\ ${ }^{1}$ Departamento de Petrología y Geoquímica, Facultad de Geología, Universidad Complutense, 28040-Madrid, Spain \\ ${ }^{2}$ Instituto Geológico y Minero de España, C/ Ríos Rosas, 23, 28003-Madrid, Spain \\ e-mail: mesanz@geo.ucm.es
}

\begin{abstract}
Based on petrographic, mineralogical, isotope, and facies assemblage analysis, a microbial origin is established for the formation of dolomite associated with gypsum in Miocene evaporite lake deposits of the Madrid Basin, central Spain. In these deposits, dolomite is present as both intercalated carbonate beds, locally showing domal stromatolite structures between packages of selenite Christmas tree-like gypsum, and patches replacing macrocrystalline gypsum.

Texture of the dolomite is characterized by crystal aggregates showing a variety of crystal sizes and morphologies, e.g., platelets, rhombs, micro-rods, and rings, whilst larger crystals are commonly spherical and/or wheat-grain shaped. Organic remains, in the form of filaments, shrubs, micro-fibrils, and strands, are also common and contain significant amounts of carbon. These textural features are also recognized in dolomite replacing gypsum, where Fe oxide and sulfide as well as celestite are ubiquitous mixed with the dolomite groundmass. The dolomite, whether primary or replacing gypsum, is poorly ordered and slightly Ca-rich, thus non stoichiometric. Stable-isotope compositions are characterized by negative values for both oxygen and carbon. Dolomite beds featuring domal stromatolites have $\mathrm{d}^{18} \mathrm{O}$ values ranging from $22.99 \%$ and $23.79 \%$ and $\mathrm{d}^{13} \mathrm{C}$ values ranging from $24.67 \%$ and $27.35 \%$, whilst $\mathrm{d}^{13} \mathrm{C}$ values determined in the dolomite replacive of gypsum shows a small range of variation between $25.70 \%$ and $26.96 \%$. By contrast, $\mathrm{d}^{18} \mathrm{O}$ values of replacive dolomite oscillate in a wider range (from $23.04 \%$ to $27.99 \%$ ).

Formation of the dolomite was associated mainly with microbial mats, having taken place in relatively diluted lake water. Further evaporative concentration resulted in precipitation of gypsum crystals sealing the mats and creating endoevaporitic microenvironments in which endolithic cyanobaterial activity produced extensive boring and corrosion of the gypsum crystals. Hiatuses in gypsum growth caused an intensification of the corrosion process and favored the precipitation of dolomite mediated by microbes, resulting in pervasive replacement of the sulfate.
\end{abstract}

\section{INTRODUCTION}

Dolomite is a rather common mineral in saline lakes (Eugster and Hardie 1978; Last 1990). Yet formation of dolomite under earth surface conditions is still a matter of controversy because of physicochemical constraints for the formation of dolomite under low pressure and ambient temperature conditions (McKenzie 1991). To solve this problem Vasconcelos et al. (1995) and Vasconcelos and McKenzie (1997) have demonstrated the decisive role of microbial mediation in the formation of dolomite from some modern evaporite lake settings. Accordingly, kinetic inhibitors for dolomite formation can be overcome in environments where microbial metabolic reactions allow the nucleation of dolomite.

The presence of microbial communities in continental and coastal marine evaporite environments, i.e., lakes, sabkhas, chotts, and salterns, where gypsum precipitates, is well documented (e.g., Gerdes et al. 1985; Arp et al. 1999). However, the endoevaporitic character of some microbial communities has not been properly outlined yet, except for a few case studies from modern saline lakes (Rothschild et al. 1994; Oren et al. 1995; Douglas and Yang 2002). Adaptation of microbes to endoevaporitic conditions provides a chance for survival under extreme environments, including those from other planets (Rothschild 1990).
This paper describes dolomite occurrences in saline lake deposits of Miocene age from the Madrid Basin, central Spain. Petrographic, mineralogic, and geochemical insight indicates that dolomite formation in these deposits was microbially mediated. Moreover, the presence of dolomite as a replacement product after gypsum could result from boring and further precipitation of dolomite, both processes being conducted by the activity of endoevaporitic microbial communities.

The role played by microbes, in particular sulfate-reducing bacteria in carbonate replacement after sulfate, has been widely recognized (Machel 2001). Calcite and, subordinately, aragonite are the common products of the replacement process. Gypsum replacement by dolomite is, however, an unusual process so far documented only for marine evaporite deposits (Pierre and Rouchy 1988).

\section{GEOLOGICAL CONTEXT}

The dolomite studied in this paper is included in a 50-m-thick evaporite formation referred to as the Christmas-tree gypsum unit (Rodri'guez-Aranda et al. 1995), which is exposed along a $30 \mathrm{~km}^{2}$ area in the easternmost part of the Madrid Basin, in the center of the Iberian Peninsula (Fig. 1). The basin is a large intracratonic structure in which 


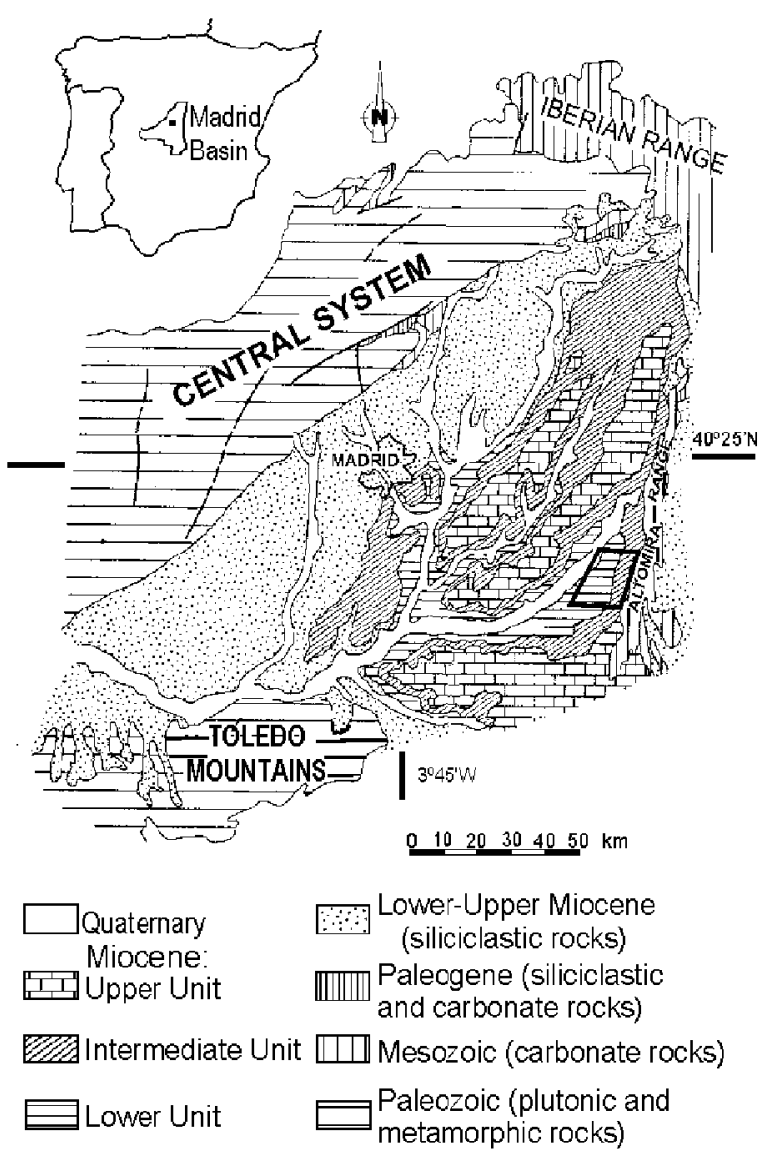

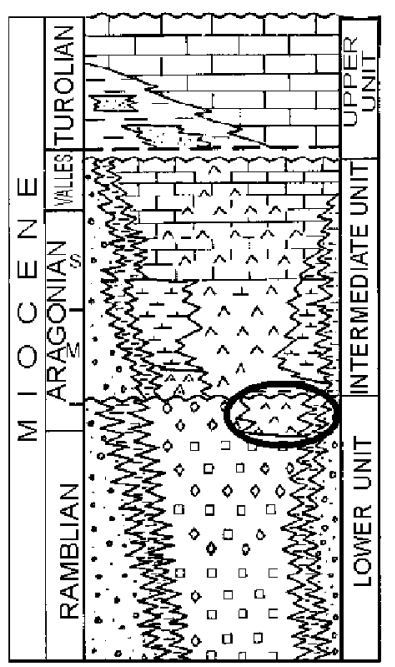

\begin{tabular}{|c|c|}
\hline \multirow{2}{*}{\multicolumn{2}{|c|}{ 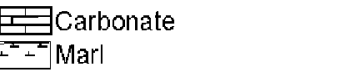 }} \\
\hline & \\
\hline & Gypsum \\
\hline & Detrital gypsum \\
\hline & Sandstone-conglon \\
\hline & $\begin{array}{l}\text { Mudstone-siltstone } \\
\text { Halite and other salts }\end{array}$ \\
\hline
\end{tabular}

FIG. 1.-Geological map of the Madrid Basin and lithostratigraphic sketch of the Miocene units. Encircled areas indicate geographic loca-tion and stratigraphic situation of the Christmas-tree gypsum unit, respectively. a succession of terrestrial sediments exceeding 2,000 $\mathrm{m}$ in thickness accumulated throughout the Tertiary (Calvo et al. 1994; Alonso-Zarza et al. 2002). The Miocene stratigraphic record of the basin is divided into three main lithostratigraphic units: Lower (Ramblian and early Arago-nian), Intermediate (Aragonian to early Vallesian) and Upper (Vallesian to Turolian) Miocene units (Fig. 1). The Lower Miocene Unit, ranging from 500 to $600 \mathrm{~m}$ in thickness, consists mainly of halides, sodium and calcium sulfates, and carbonate and mudstone deposits that accumulated in hypersaline lakes (Ordo ' $n \sim$ ez et al. 1991). The lake deposits interfinger with terrigenous deposits towards the basin margins according to a typical alluvial-saline-lake concentric pattern characteristic of a hydrologically closed basin (Eugster and Hardie 1978).

The Christmas-tree gypsum unit is located at the top of the Lower Miocene Unit and comprises eight superimposed sedimentary sequences that are formed of mudstone, marlstone, primary gypsum, and secondary gypsum after anhydrite and dolomite. One striking feature of the primary gypsum is that it exhibits an unusual morphology characterized by twinned selenite crystals in which the reentrant angle systematically opens downward, which is in contrast to the classical Mottura's rule pattern commonly observed in selenite gypsum crystals (Ogniben 1954; Schreiber 1978).

The gypsum and associated deposits accumulated in a peripheral lake that was isolated from a larger hypersaline lake spreading on the center of the basin during the early Aragonian (Fig. 1) (Rodríguez-Aranda et al. 1995).

\section{FACIES ASSOCIATIONS AND PALEOENVIRONMENT}

The basic sedimentary sequence recognized in the Christmas-tree gypsum unit comprises three main facies associations (Fig. 2). The lower

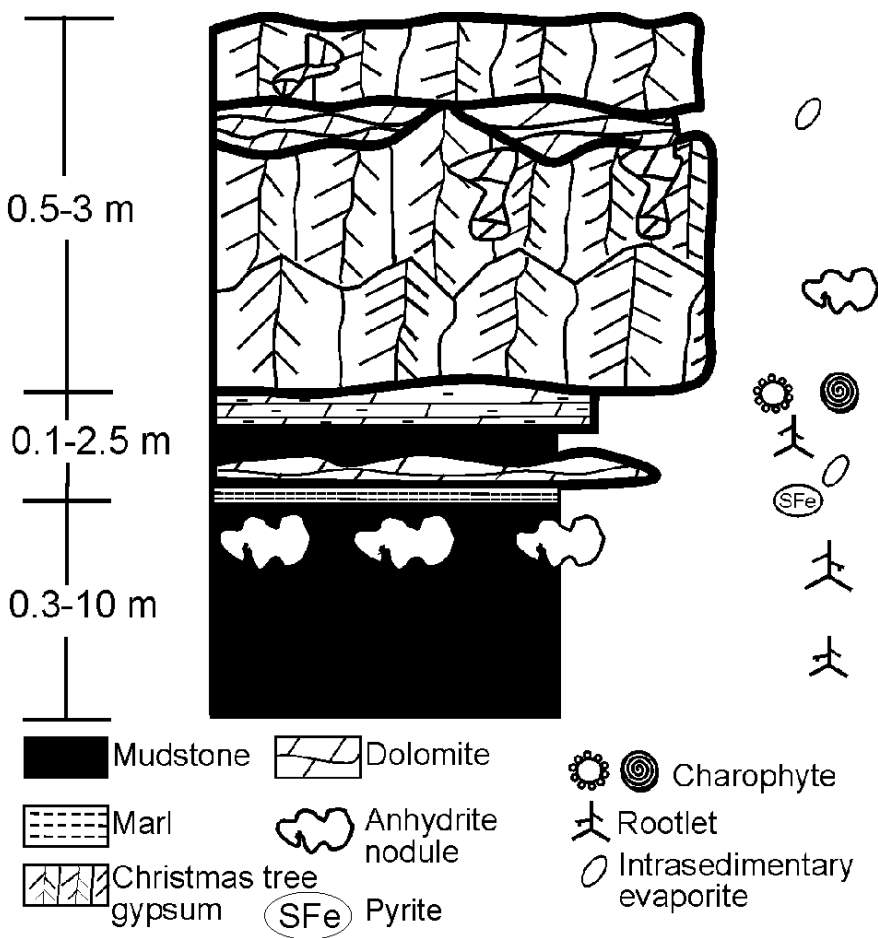

FIg. 2.-Typical sedimentary sequence of the Christmas-tree gypsum unit. 

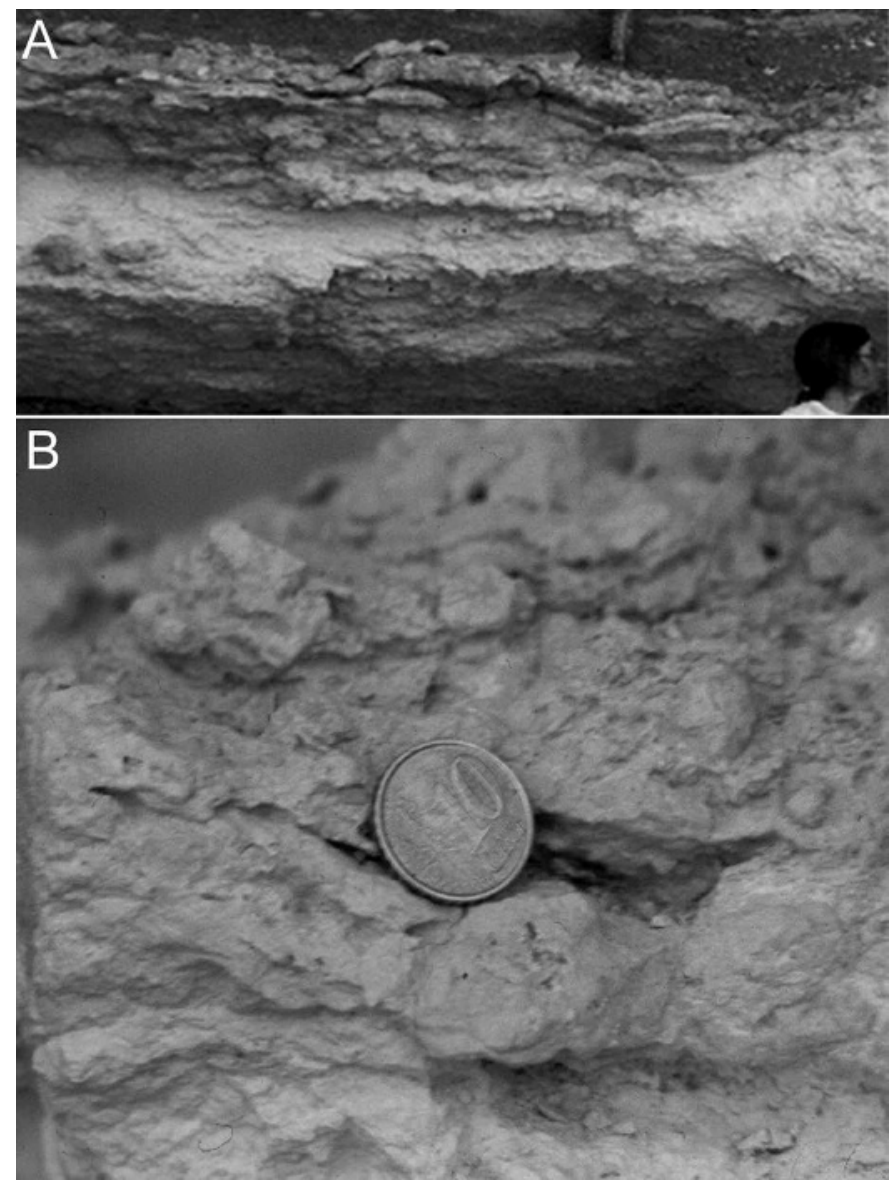

FIG. 3.- Dolomite beds in the middle part of the sequence. A) Outcrop photograph showing the laminar structure and dome-shapes, especially towards the upper part of the dolomite bed. B) Hand sample showing undulate layering and porosity characteristic of stromatolites. Coin for scale is $2 \mathrm{~cm}$ in diameter.

part of the sequence consists of brown to green mudstone which shows abundant gypsum nodules after anhydrite and root bioturbation (Rodríguez-Aranda 1995).

The middle part of the sequence is composed of green mudstone, greenish-gray magnesitic marlstone, and whitish dolomite beds. The deposits show displacive gypsum nodules after anhydrite, molds and/or pseudomorphs of intrasedimentary hemypiramidal (probably gypsum and/or glauberite) crystals, and abundant rootlets. Iron sulfide and iron oxide and hydroxide are ubiquitous, and the mudstone occasionally smells of $\mathrm{H}_{2} \mathrm{~S}$. Dolomite is present as laterally continuous, tabular, centimeter- to decimeter-thick beds, although locally it occurs as domeshaped structures reaching up to $20 \mathrm{~cm}$ in diameter. The internal structure of the dolomite beds is massive to laminated (Fig. 3 A, B) Dolomite microfacies consists mainly of bindstone, characterized by massive clotted and/or laminated fenestral micrite and microsparite (Fig. 4). Dolomite wackestone showing gyrogonites and charophyte stems occurs locally, especially at the base of some dolomite beds.

Facies association in the upper part of the sequence comprises mainly gray to greenish gypsum and white to beige dolomite, with local overprints of replacive and displacive anhydrite nodules (Fig. 2). The gypsum consists of large growth-aligned selenite crystals twinned along (100), reaching up to 10 $\mathrm{cm}$ in width (Fig. 5A), up to $30 \mathrm{~cm}$ in high, and several decimeters in horizontal length. As mentioned above, the twin reentrant angles of the gypsum aggregates invariably open downward (see Rodríguez-Aranda et al. 1995 for a more complete description of the

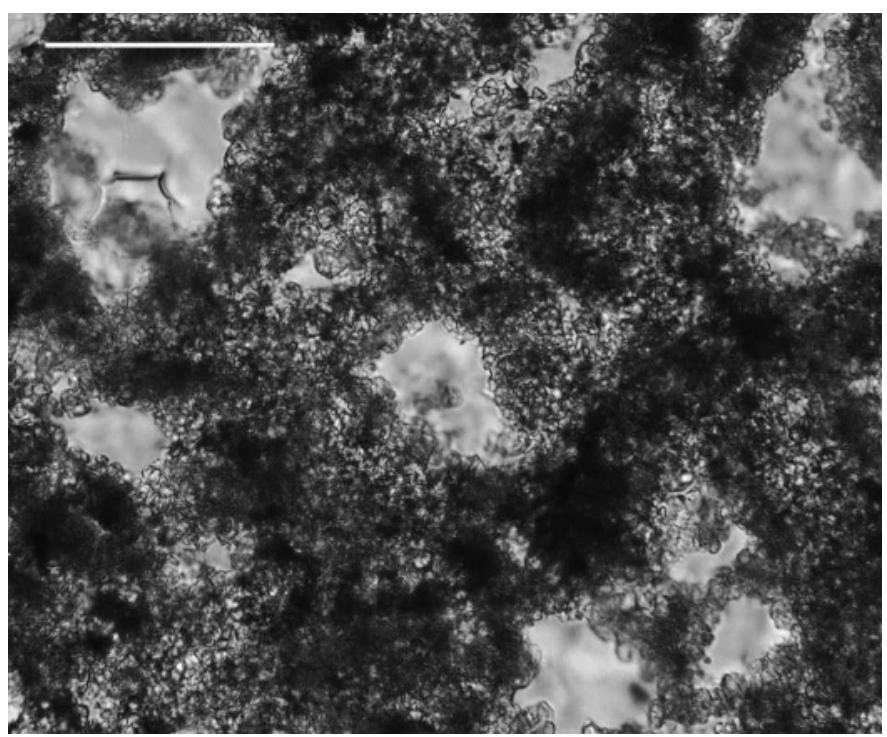

FIG. 4.- Photomicrograph under polarized plane light of a domal shaped dolomite bed showing clotted texture and fenestral porosity. Scale bar $60 \mathrm{~mm}$.

selenite gypsum). The gypsum forms laterally continuous beds $0.5-3 \mathrm{~m}$ thick (Fig. 2). Each bed is in turn made up of different layers, ranging from 8 to $30 \mathrm{~cm}$ in thickness, separated by flat planation surfaces or by zigzag surfaces preserving the upper outlines of the crystals. Laterally discontinuous, centimeter-thick dolomite beds displaying domal to pustular morphologies overlie the gypsum bed surfaces. Isolated, stromatolite domes up to $50 \mathrm{~cm}$ wide are locally observed (Fig. 6A, B). Thin laminated dolomite is the usual internal structure of the domes, although dolomite is locally massive.

The presence of dolomite replacing gypsum is remarkable at the boundaries between the selenite Christmas-tree gypsum packages and the interbedded dolomite stromatolites. A web of corrosion veins filled with dolomite that penetrate several centimeters downwards, or, in a few cases, upwards from the gypsum, sprouts from the dolomite beds (Fig. 6B), resulting in extensive replacement of the aggregates of Christmas-tree gypsum by dolomite (Fig. 5B).

\section{Paleoenvironmental Interpretation}

Root-bioturbated brown to green mudstone containing gypsum nodules after anhydrite forming the lower part of the sequences of the Christmas-tree gypsum unit has been interpreted as typical of a saline mudflat subenvironment (Rodr1'guez-Aranda 1995). Upward in the sequence, greenish mudstone with intercalated dolomite beds showing domal morphologies represents the transition from a saline-mudflat to a lacustrine-margin subenvironment. The dolomite beds are interpreted as planar and dome stromatolites resulting from lithification of microbial mats developed in the lake margin (Sanz-Montero et al. 2003). The presence of sulfate nodules and intrasedimentary gypsum (probably related to glauberite precursors) in the mudstone and the dolomite suggests short-term periods of higher evaporation rates succeeding periods when the lake water was more diluted.

The Christmas-tree gypsum and associated dolomite of the upper part of the sequence are interpreted as accumulated in a saline lake environment. Rodri'guez-Aranda et al. (1995) concluded that the formation of the special selenite fabric represented by the Christmas-tree gypsum took place from brines dominated by $\mathrm{Ca}-\mathrm{Na}-\mathrm{SO}_{4}-\mathrm{Cl}$ and a relatively high content of organic compounds derived from terrestrial plants or other organisms common in saline environments (Cody and 

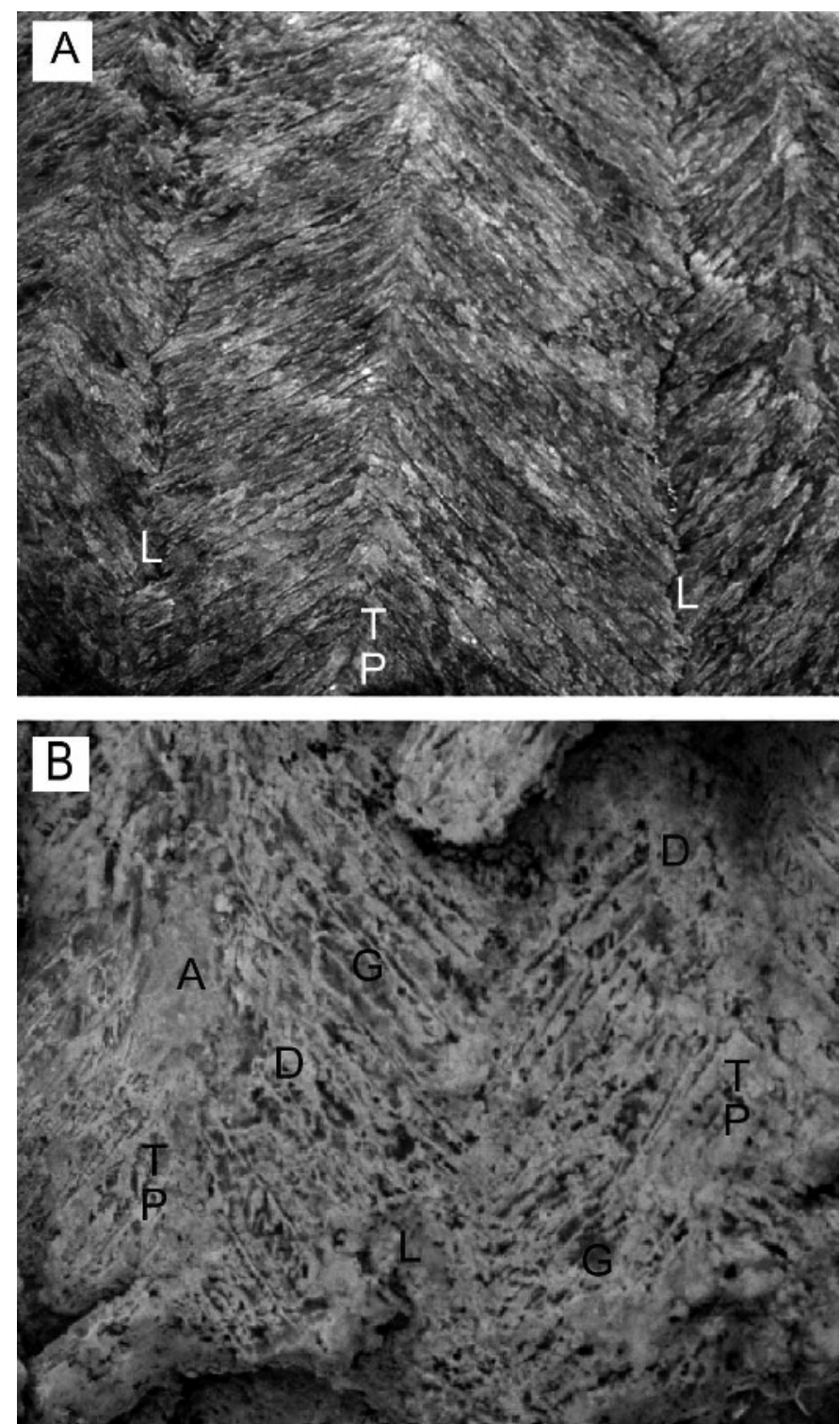

Fig. 5.- Close-up views of the Christmas-tree gypsum beds. Both sections are parallel to (010) main cleavage. A) Gypsum is made up of growth-aligned crystal formed as aggregates of downward-oriented simple twins. B) Gypsum bed showing extensive replacement by dolomite. G, gypsum; D, dolomite; A, secondary gypsum after anhydrite, Tp, trace of the twin plane; L, crystal limit. Height of the photographs is $15 \mathrm{~cm}$.

Cody 1988; DeDeckker 1988). Ayllo' n-Quevedo et al. (2005) have estimated that total salinities leading to precipitation of the selenite gypsum could range from 2 to 9 eq. $\mathrm{Wt} / \% \mathrm{NaCl}$. The intercalated dolomite beds formed on the gypsiferous ground during dilution stages of the evolution of the lake, as inferred from the negative $\mathrm{d}^{18} \mathrm{O}$ values of the carbonates (Table 1) and recognition of dissolution surfaces on the gypsum top beds, further overlain by dolomite (Fig. 6). Under these conditions, punctuated desiccation events took place, as reflected by the presence of early diagenetic anhydrite nodules replacing both parallel-sided gypsum crystals and dolomite beds (Fig. 5B) This feature is strongly indicative that dolomite was a synsedimentary product, prior to the growth of the anhydrite nodules (Rodri'guez-Aranda et al. 1995).
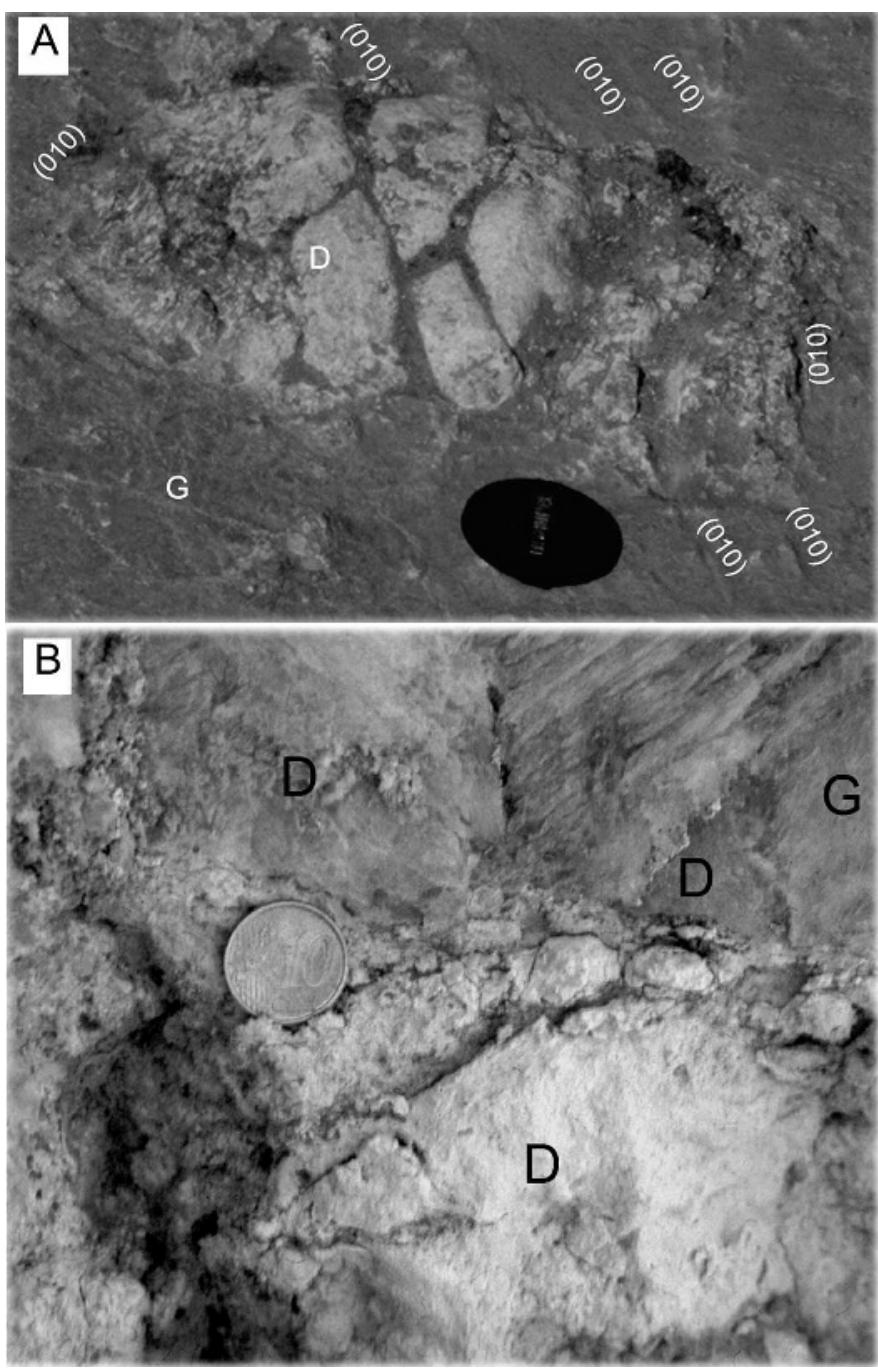

FIG. 6.- Outcrop views of dolomite stromatolite beds intercalated in gypsum. A) Plan view of a dolomite dome (D) developed on a flat planation gypsum surface (G). The dome shows a reticulate morphology at the center of the bed top; left and right sides of the dome and below, dolomite is observed to replace gypsum along the (010) main cleavage planes of the subcrystals, thus showing the intrinsic relation between the domes and replacive dolomite. B) Vertical section of dolomite interbedded with gypsum. The dolomite is massive, passing upwards into thinly laminated dolomite. Some patches of replacive dolomite can be observed in the gypsum bed. Coin for scale is $2 \mathrm{~cm}$ in diameter.

Replacement of gypsum by dolomite is considered to have been an early diagenetic process. Specific features of the replacing dolomite are described and discussed below.

\section{SEM PETROGRAPHY AND COMPOSITION OF DOLOMITE}

Samples from dolomite beds in the sequence as well as from dolomite replacing the Christmas-tree gypsum were systematically analyzed by SEM imaging under a JEOL JSM-6400 apparatus provided with an energy-dispersive spectrometry device (EDS). Electron-microprobe (EMP) analyses of samples were carried out in wavelength-dispersive mode, using a JEOL Superprobe JXA 8900-M equipped with four crystal spectrometers. Operating conditions were: acceleration voltage of $20 \mathrm{kV}$ and probe current of $50 \mathrm{nA}$, with variable counting times between 10 and 30 seconds and between 5 and 15 seconds, in peak and background, respectively. Beam diameter was between $2-5 \mathrm{~mm}$ to minimize damage 
TABLE 1.- Mineralogical and compositional features of the dolomite beds in the different parts of the sedimentary sequence (Fig. 2) as determined by XRD, microprobe, and isotopic techniques. According to Hardy and Tucker (1988), the degree of ordering in dolomite 5 intensity 015 peak/ intensity 110 peak, and the mole $\% \mathrm{CaCO}_{3}$ in dolomite $5333.333 \mathrm{~d}_{104}+(-911.99)$. Nu 5 number of samples.

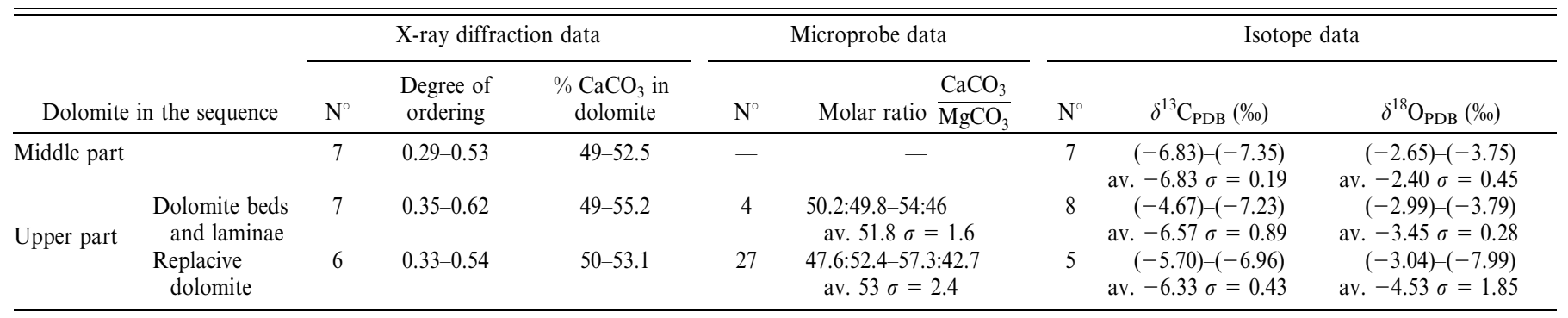

from the electron beam. To examine the compositional heterogeneities of the samples, backscattered electron imaging was used.

Fluorescence of samples was observed under excitation with UV light in fluorescence microscopy.

X-ray diffraction was used to determine mineral composition in 20 powdered carbonate samples, using quartz as an internal standard. The equipment used was a Philips X-ray diffraction system operated at $40 \mathrm{kV}$ and $30 \mathrm{~mA}$, and monochromated $\mathrm{CuK}_{\mathrm{a}}$ radiation. Semiquantitative estimates of relative percentages of minerals from whole-rock samples were made through measurement of intensity of the diffraction peaks by integration of the area. Values of $\mathrm{mol} \% \mathrm{CaCO}_{3}$ of the carbonate minerals were estimated by measurement of the position of the $d_{104}$ peak relative to a standard (Goldsmith et al. 1961). The degree of ordering of the dolomite crystals was determined by the sharpness and relative intensities of the ordering peaks, superstructure reflections corresponding to $d_{021}, d_{015}$, and $d_{110}$ (Goldsmith and Graf 1958). The degree of ordering is thus estimated by the ratio of the heights of the ordering peak 015 to the diffraction peak 110 (Hardy and Tucker 1988).

For stable-isotope analysis, 20 dolomite samples were ground to pass through a 100 mesh sieve; the 250 mesh fraction was saved for analysis. Carbon dioxide was evolved from each sample at $25 \mathrm{uC}$ using $100 \%$ $\mathrm{H}_{3} \mathrm{PO}_{4}$. The gas evolved in the first hour was attributed to calcite; the gas evolved between $24 \mathrm{hr}$ and 7 days was attributed to dolomite. All samples were prepared and analyzed at least in duplicate. The analytical precision is generally $60.10 \%$ for carbon and $60.15 \%$ for oxygen. Both oxygen and carbon values are reported in permil relative to PDB (Table 1).

Under SEM, texture of the dolomite from beds in both the middle and upper part of the sequence is characterized by open aggregates of micrite and microsparite crystals in which a variety of crystal sizes and habits can be recognized. The micrite crystals show varied morphologies (platelets, rhombs, micro-rods, and rings) whilst microsparite is commonly spherical and wheatgrain shaped (Fig. 7). The microsparite crystals display cores, spheroid to dumbbell in shape, which contain organic remains (Fig. 8). Commonly, the microsparite crystals exhibit a ropy appearance due to the presence of microfibrils, rods, spheres, and films that are irregularly distributed on their surfaces. Separation between crystals is also spanned by strands and fibrils that contain a significant amount of carbon, as revealed by using EDS under SEM. In many cases, the dolomite crystals are arranged around tubular molds reaching up a few microns in diameter, and, locally, the tubular microstructures form clusters displaying shrub morphologies. Carbon-rich, rounded microstructures $5-10 \mathrm{~mm}$ in diameter resembling cyanobacteria sheaths occur associated with the dolomite crystals (Fig. 8). Celestite showing prismatic and tabular habits is common in the dolomite aggregates (Fig. 7) (Rodri'guez-Aranda et al. 2005).

Replacive dolomite in gypsum (Fig. 5B) is characterized by textures basically similar to those observed in the dolomite beds (Fig. 9). Moreover, some remains of organic matter are preserved in the replacing dolomite, as recognized under SEM and microprobe analysis but also marked by greenish fluorescence of the dolomite groundmass (Machel et al. 1991). Fe oxides, pyrite, and celestite minerals are ubiquitous in the replacing dolomite. Celestite crystals occur intimately associated with dolomite and often embedded in organic matter, which tie both minerals genetically (SanzMontero et al. 2005; Rodri' guez-Aranda et al. 2005).

Mineralogical analysis reveals that the carbonate is nearly pure dolomite. The degree of ordering in the dolomite samples, determined by measurement of indices 015 and 110 from X-ray traces, ranges from 0.29 to 0.53 in samples collected from dolomite beds in the middle part of the sequences and from 0.35 to 0.62 in dolomite beds intercalated between the Christmas-tree gypsum (Table 1). These values indicate that the dolomites are poorly ordered (Kinsman 1964, cited in Bathurst 1975). According to the $\mathrm{mol} \% \mathrm{CaCO}_{3}$ values determined in the dolomites (49$55.2 \mathrm{~mol} \% \mathrm{CaCO}_{3}$ ), these can be characterized as slightly Ca-rich, thus nonstoichiometric. The assessment is valid also for the dolomite replacing the Christmas-tree gypsum, which is in the same range of ordering degree and mol\% $\mathrm{CaCO}_{3}$ values (Table 1). Molar ratios obtained from microprobe analyses also reflect that most of the dolomite samples are enriched in $\mathrm{Ca}$.

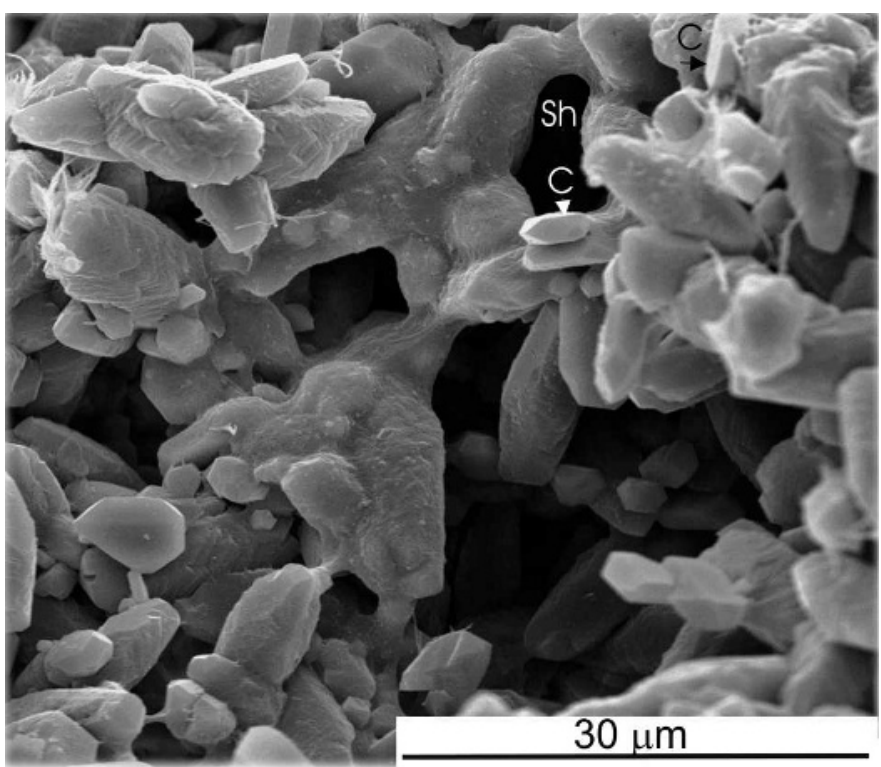

FIG. 7.- SEM image of dolomite from the middle part of the sequence showing the distribution and variety of size and shapes of the dolomite crystals. Note fixation of the dolomite crystals on C-rich sheaths (Sh) and presence of C-rich microfibrils and strands of mucilage spanning the distance between crystals. Celestite $(\mathrm{C})$ is present as euhedral crystals linked to dolomite. 


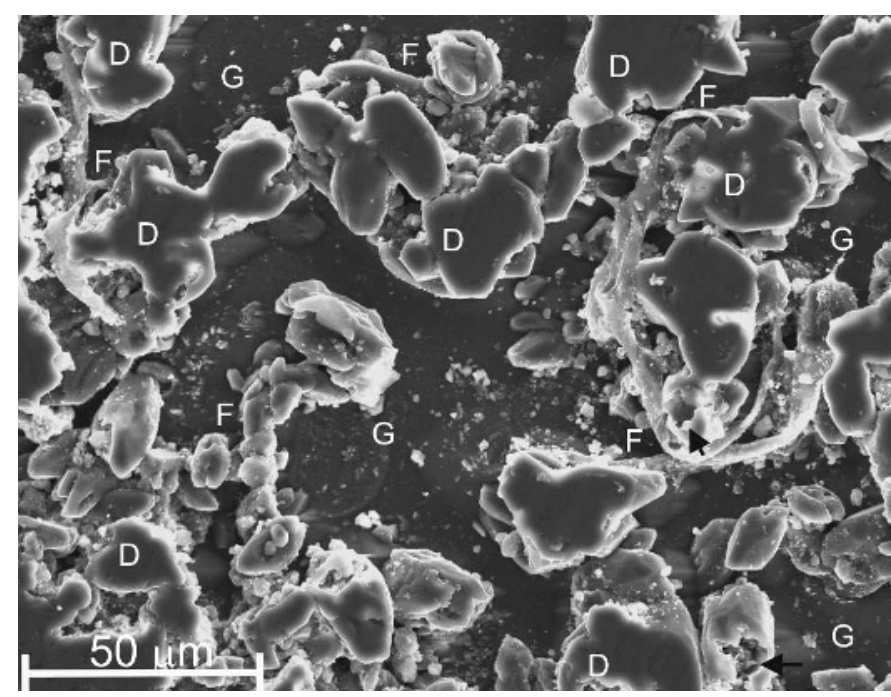

FIG. 8.- SEM image from a polished slab showing the presence of C-rich filaments (F) encrusted with dolomicrosparite crystals (D). Some dolomicrosparite crystals containing organic inclusions in cores are arrowed.

The isotopic composition of the dolomite samples from the middle and upper part of the sequences is characterized by negative values for both carbon $\left(\mathrm{d}^{13} \mathrm{C}\right.$ ranging from $24.67 \%$ and $\left.27.35 \%\right)$ and oxygen $\left(\mathrm{d}^{18} \mathrm{O}\right.$ ranging from $22.99 \%$ and $23.79 \%$ ) (Table 1 ). In addition, the $\mathrm{d}^{13} \mathrm{C}$ values of the replacive dolomite show a small range of variation between $25.70 \%$ and $26.96 \%$. By contrast, the $\mathrm{d}^{18} \mathrm{O}$ values of replacive dolomite oscillate in a wider range, between $23.04 \%$ and $27.99 \%$.

Therefore, the three occurrences of dolomite are significantly enriched in ${ }^{12} \mathrm{C}$, which supports the incorporation of organically derived carbonate ions in the mineral. On the other hand, depleted ${ }^{18} \mathrm{O}$ isotopic values in the carbonate indicate that the lake water from which they precipitated was relatively diluted.

The textural, compositional, and structural features of the dolomite resemble those described by Vasconcelos and McKenzie (1997) and Wright (1999) from modern lakes, where microbially mediated dolomite is forming. Both in Lagoa Vermelha and other Brazilian coastal lagoons (Vasconcelos and McKenzie 1997) and in the Coorong lakes of South Australia (Wright 1999; Wright and Wacey 2005), dolomite precipitates as a poorly crystallized mineral, exhibiting no regular habits and knobby surfaces. Similarly to the dolomites studied in the Miocene lake deposits of the Madrid Basin, dolomite sediments from the above-mentioned modern lakes, in particular those analyzed by Vasconcelos and McKenzie (1997), are typically formed of Ca-rich dolomite, and their $\mathrm{d}^{13} \mathrm{C}$ values are in the same range as those measured in the Madrid dolomites.

\section{EVIDENCE FOR MICROBIAL ACTIVITY IN GYPSUM}

\section{Gypsum Crystallography}

Christmas-tree gypsum macrocrystals actually consist of millimeter-to centimeter-size subcrystals that grew epitaxially according to a regular pattern (Fig. 5A) (Rodri'guez-Aranda et al. 1995). The boundaries of the gypsum subcrystals appear unevenly outlined by dolomite laminae, fossil organic matter, and micro-dissolution surfaces along $\left\{1^{-} 11\right\},\{120\},(100)$, and (020) crystal faces (Fig. 8). Faces of the family $\left\{\begin{array}{ll}1^{-} & 11\end{array}\right\}$ form the twin reentrant

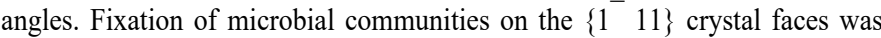
favored by slow growth rate. According to Cody and Cody (1991), the presence of organic inhibitors in the brine is probably responsible for the growth rate of such group of faces, whilst they may

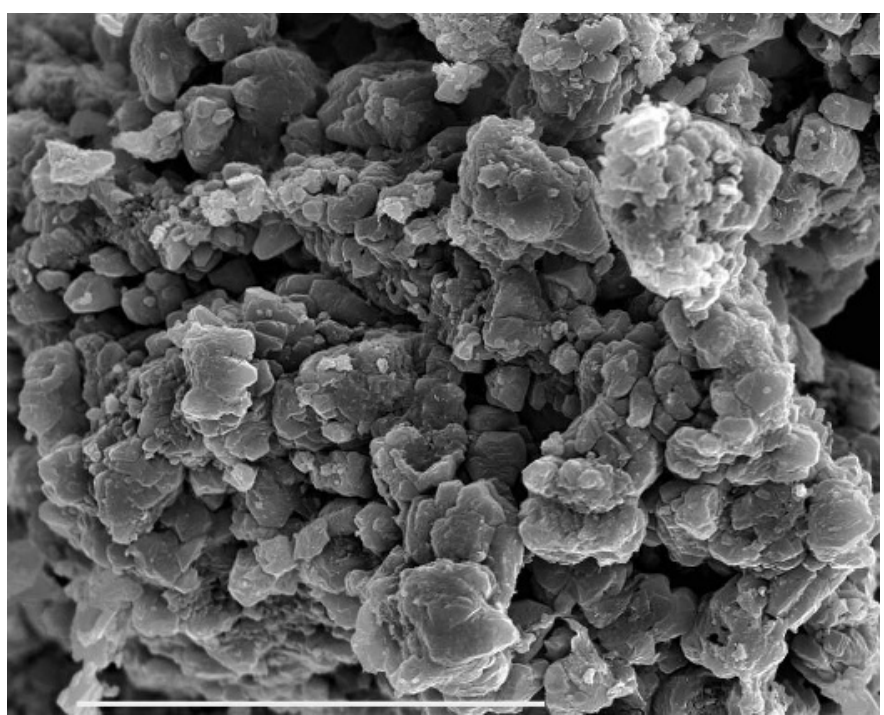

FIG. 9.- SEM image of replacive dolomite characterized by micrite and microsparite crystals exhibiting irregular habits and granular surfaces. Some crystals show hollows and form chains locally. Scale bar is $30 \mathrm{~mm}$.

favor crystal twinning along (100) and development of large gypsum crystals.

The outlines of the subcrystals suggest interruption in gypsum growth, which allowed dolomite and related organic matter fixation on the depositional surface of the gypsum crust. The uniformity in the spacing of the vertically stacked subcrystals (Fig. 5A) can be interpreted as seasonal dilution events, probably correlative with input of meteoric water into the lake. Negative $\mathrm{d}^{18} \mathrm{O}$ values of the dolomite laminae also support this interpretation.

\section{Dolomite and Microbial Organic Matter Outlining Gypsum Subcrystals}

The presence of fossil organic matter overlying the subcrystal outlines and filling up micro-dissolution fissures is highlighted by using fluorescence techniques and scanning electron microscopy. The C-rich luminescent remains consist mainly of microfibrils, films, and microstructures, showing spheroidal and filamentous shapes. Spheroidal microstructures, ranging from 3 to $5 \mathrm{~mm}$ in diameter, occur aligned or grouped in pairs and in distinctive tetrads (Fig. 10B). Filaments are 10 $\mathrm{mm}$ in diameter and more than $100 \mathrm{~mm}$ in length (Fig. 8). Curved filaments, showing a banded pattern indicative of different stages of growth, are also discernible under the fluorescence microscope. All these features including composition, size, shape, and organization allow for interpretation of the organic remains associated with dolomite as related to the growth of cyanobacterial biofilms (Arp et al. 1999). In this context, the arrangement of spheroidal microstructures to clusters is typical of microbial colonies and, particularly, of coccoid cyanobacteria. In biofilms, coccoid taxa coexist with elongated filamentous forms, all embedded by extracellular polymeric substances, EPS, and mucus (Noffke et al. 2003). Mucal strands and EPS may be desiccated, giving place to unstructured fibrils and deflated films (Renaut et al. 1998), similar to those recognized in the dolomite laminae (Fig. 10C).

The cyanobacterial biofilms are mineralized into dolomite crystals showing varied size (Figs. 8, 10B, C, 11). Collapsed filaments and filmlike microstructures are covered by small dolomite crystals. Mineralization of coccoid microbes takes place as minute crystallites on the surface of the cells (Fig. 10B). In other cases, spheroidal crystals consist of an arrangement of thin dolomite platelets oriented tangentially around the core of the crystal. Crystals may develop rhomb-shaped terminations 

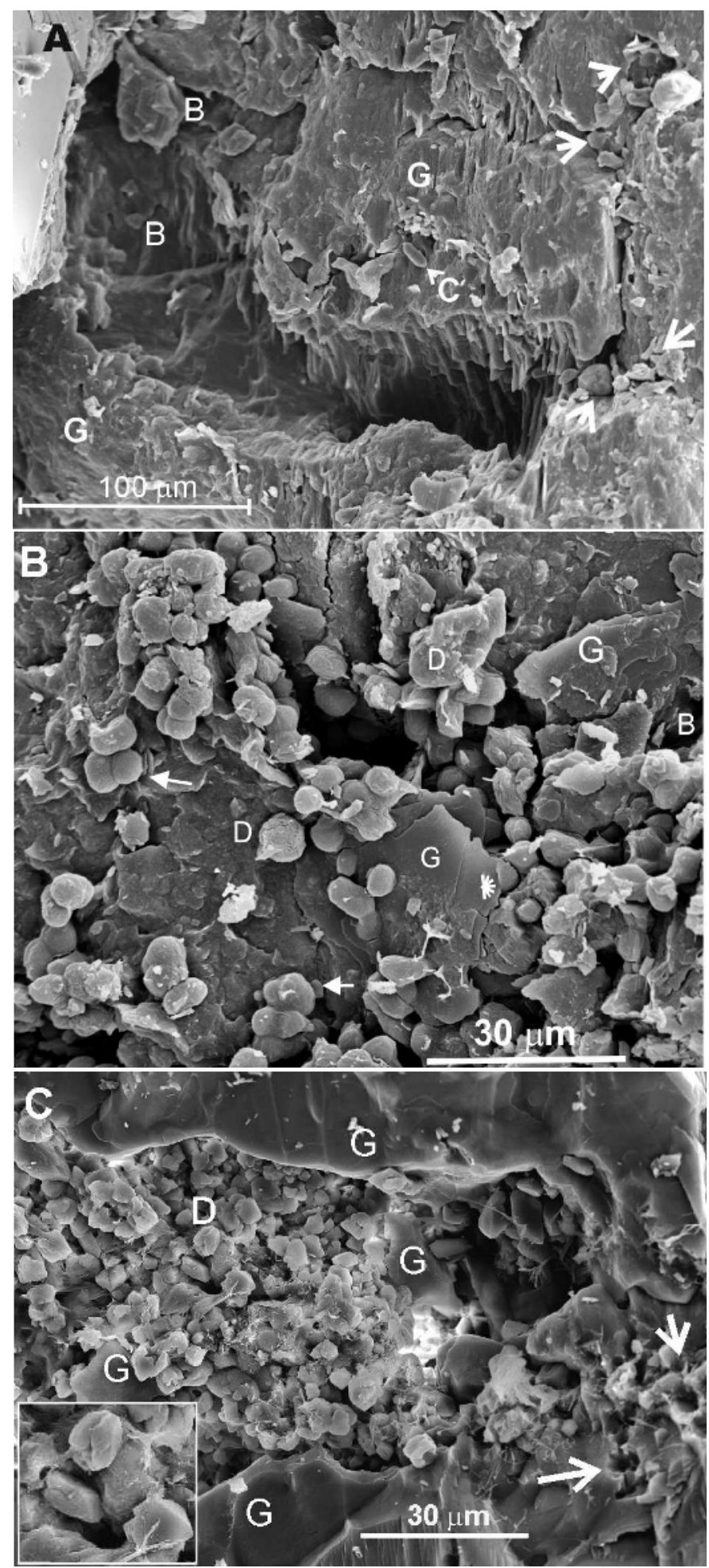

FIG. 10.- SEM images showing relations between gypsum and dolomite crystals. A) Typical aspect of empty bores in gypsum crystals. Some organic remains, dolomite (arrows), and celestite crystals (C) outline the dissolution features. Parallel planes arranged vertically in the photograph correspond to (010) cleavage of the gypsum crystals. B) C-rich coccoid-like microstructures outlining gypsum bores and surfaces show similar spherical morphologies and sizes. The coccoids occur grouped in tetrads (arrowed) or as strings joined by strands. Coccoid forms are partially mineralized into dolomite. Ropy appearance of gypsum is due to the presence of an organic-matter film. Arrowhead symbol in the

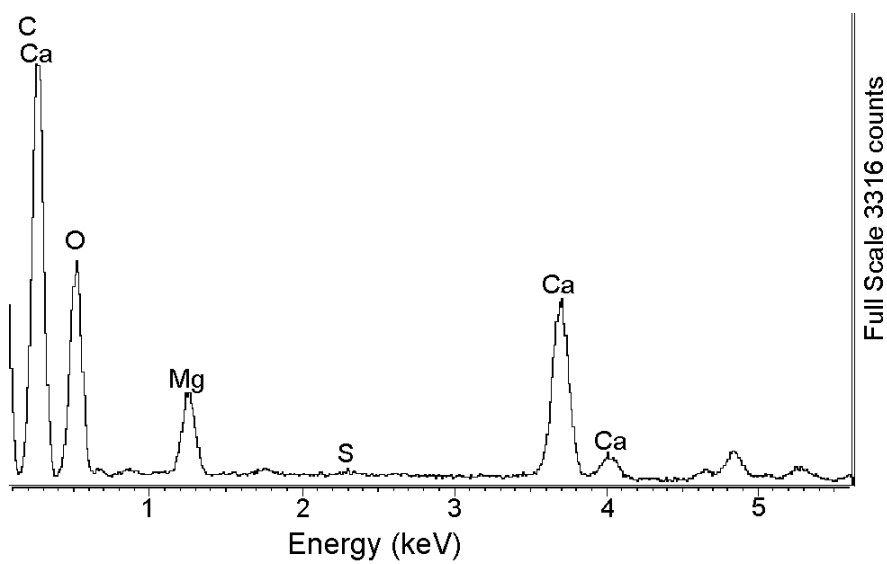

FIG. 11.- EDS analysis showing the typical composition of the dolomite crystals shown in Figure 10C.

towards the edges (Sanz-Montero et al. 2005). Filamentous forms occur encrusted with dolomicrosparite crystals that range from 5 to $15 \mathrm{~mm} \mathrm{i} \mathrm{n}$ diameter and exhibit spheroidal habits and wheat-grain morphologies (Figs. 8, 10B). The inner part of the crystals is commonly empty and/or contains some C-rich remains (Figs. 8, 10C, 11).

Early, organically controlled precipitation of carbonates and other minerals in recent microbial mats and biofilms largely has been documented (Kempe and Kazmierczak 1993; Gerdes et al. 1994; Folk and Chafetz 2000; Arp et al. 2003). Biogenic carbonate minerals are generally characterized by a high structural diversity (Gerdes et al. 1994; Wright 1999). In many cases, carbonates precipitate around living cyanobacterial cells and filaments (Noffke et al. 2003; Kazmierczak and Kempe 2004), which account for the formation of globular crystals with inner holes representing former sites of microbial occupancy (Folk and Chafetz 2000). As observed in modern environments, spheroidal dolomite crystals similar to those described in this paper occur encapsulating microbial forms interpreted as cyanobacteria, for instance in late Pleistocene marine microbialites from Western India (Rao et al. 2003). Carbonate precipitation around the microbial cells might be favored by the concentration of $\mathrm{Ca}$ and $\mathrm{Mg}$ ions on the cell surfaces, thus creating suitable microenvironments for the carbonate formation (Castanier et al. 1999). In addition, micrite crystals in dolomite laminae outlining gypsum subcrystals occur usually associated with cyanobacterial collapsed forms, mucus, and/or microfibrils (Fig. 10B, C). According to Noffke et al.(2003), decomposition of organic material is the main process leading to carbonate precipitation in modern microbial mats. Moreover, Vasconce-los et al. (1995) and Vasconcelos and McKenzie (1997) proposed an actualistic model for dolomite formation, the microbial dolomite model, in which photosynthetically produced organic matter can be recycled microbially by sulfate-reducing bacteria. Detailed mechanisms and microenvironmental factors, i.e., supply of sulfate, ion concentration, alkalinity levels, and $\mathrm{pH}$, involved in microbially induced precipitation of dolomite have been described by Warthmann et al. (2000).

center indicates the presence of dolomite crystals causing cracking of a gypsum crystal. C) Replacive dolomite displaying a variety of sizes and shapes fills up borings in gypsum. Organic microfibrils and strands (magnified in inset) are ubiquitous in the groundmass. Aligned spherical dissolution holes joined by thin strands are arrowed; note similarity in the shape of the hole and the empty bore depicted in Part A. G, gypsum; D, dolomite; B, bore. Width of inset $515 \mathrm{~mm}$. 


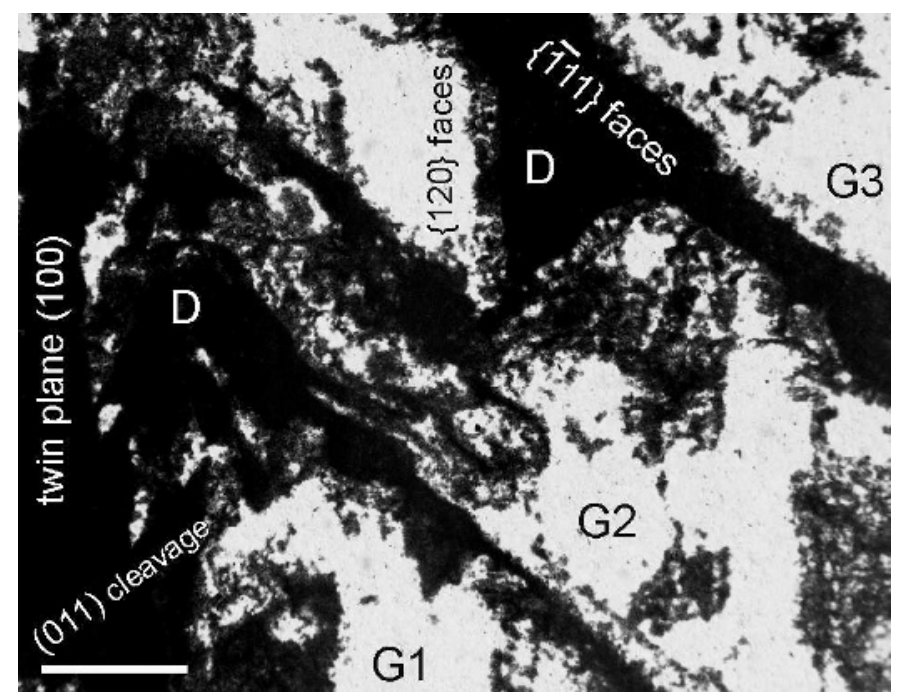

FIG. 12.- Photomicrograph under plane polarized light of gypsum partially replaced by dolomite. The section is parallel to the (010) cleavage of gypsum Labels indicate the crystallographic faces of gypsum. G1, G2, G3, successive stages of epitaxial gypsum subcrystals growth; D, dolomite. The dolomite replacemen mimics the crystallographic planes of the sulfate. Contorted tubular morphologies of microbores filled by dolomite are observed to proceed both downwards and upwards from the boundaries between subcrystals. Scale bar $5250 \mathrm{~mm}$.

\section{Micro-Dissolution Features in Gypsum}

Bores showing common cylindrical contorted morphologies that start at the outer edges of the crystals (Fig. 10A) are the most typical dissolution feature in the Christmas-tree gypsum. The bores follow several directions, mainly perpendicular to $(010)$ or $\left\{1^{-} 11\right\}$ crystal faces, ranging from 0.3 to $0.8 \mathrm{~mm}$ in length and 30 to $150 \mathrm{~mm}$ in width. The crystalline structure of the gypsum is affected by the bores in several ways: (1) cleavage of the gypsum subcrystals is widened, cut, and slightly displaced near the bores (Fig. 10A); (2) the crystals are cracked according to a zigzag arrangement that is commonly outlined by dolomite crystals (Fig. $10 \mathrm{~A}$ ); and (3) interlocking of the pits locally results in the detachment of gypsum fragments near the crystal surfaces (Fig. 10C). The bores are either empty or filled up by microbial organic remains, which are partially mineralized in dolomite (Fig. 10B). Moreover, the perforations are seen to proceed both downwards and upwards from the boundaries between subcrystals (Fig. 12).

The observed pattern of pitting, cleavage widening, cracking, and local detachment of the gypsum subcrystals is considered to be due to the boring activity of endolithic microbes, presumably cyanobacteria. Bore holes penetrating both the lower and upper gypsum crystal interfaces provide evidence that the microbial communities were active during successive episodes of crystal growth. This is in contrast to the passive enclosure of cyanobacterial filaments in selenite gypsum reported by other authors, e.g., Rouchy and Monty (2000) from Messinian evaporite formations in the Mediterranean. The microbial communities which produced boring can be characterized as "endoevaporitic communities," a concept coined by Rothschild et al. (1994) to describe microbial mats that not only thrive on the surface but also live embedded in gypsum crystals to a certain depth from the surface. Rothschild et al. (1994) pointed out that this type of microbial community, reported from modern evaporitic environments such as the Gavish sabkha (Gerdes et al. 1985), solar salterns from several regions (Caumette et al. 1994; Oren et al. 1995), and Death Valley, California (Douglas and Yang 2002), are metabolically active for at least ten months inside the gypsum crusts. In such extreme environments, cyanobacteria are able to survive because the gypsum provides a microhabitat in which the microbes are protected from adverse meteoric agents whilst it is transparent enough to allow radiation useful for photosynthesis (Rothschild 1990; Hughes and Lawley 2003).

References documenting processes of corrosion in gypsum crusts due to microbially driven dissolution are scarce. Douglas and Yang (2002) have provided insight from modern evaporite deposits of Death Valley. However, micro-boring of carbonate grains by endolithic cyanobacteria has been largely described. For instance, McIntyre et al. (2000), in their thorough study of modern marine stromatolites, observed that the apical cells of some coccoid cyanobacteria penetrate further into carbonate grains even at the time the cells are dividing.

\section{GYPSUM REPLACEMENT BY DOLOMITE}

The presence of dolomite replacing gypsum is remarkable at the boundaries between the selenite Christmas-tree gypsum packages and the interbedded dolomite stromatolites (Fig. 6). Therein, the gypsum crystals show abundant corrosion features and pervasive replacement by dolomite, which usually mimics the crystalline pattern of the gypsum (Fig. 5B). Detailed microscopic observations under plane-polarized microscope and SEM allow recognition of the evolutionary pattern of both corrosion and replacement phenomena within the gypsum crystals (Fig. 12): (1) Incipient replacement is outlined by microbores filled up by dolomicrite and/or dolomicrosparite; (2) the replacing dolomite crystals progress mainly at the outer edges of the gypsum crystals and subcrystals; and (3) replacement by dolomite proceeds further throughout the twinning and cleavage planes of gypsum. This results in a complex array of dolomicrite in which isolated gypsum patches are recognized (Fig. 5B).

Replacive dolomite is characterized by a high structural diversity, and in many cases, consists of spheroidal crystals with inner holes (Fig. 9). The crystals occur intimately associated with celestite, pyrite, or Fe oxides after pyrite, and organic matter that binds $\mathrm{Mg}$ and $\mathrm{Ca}$ (Fig. 13).

Based on the described features and the close relationship between the replacive dolomite and the stromatolite beds and laminae (Figs. 6, 8, 12), formation of dolomite as a replacement product after gypsum is considered to have been related to the metabolic activity of sulfate-reducing bacteria, the uptake of $\mathrm{SO}_{4}{ }^{22}$, and further release of $\mathrm{Mg}^{2+}, \mathrm{C} \mathrm{a}^{2+}$, and $\mathrm{CO}_{3}{ }^{22}$ ions, all these factors contributing to precipitation of dolomite (Vasconcelos et al. 1995; Vasconcelos and McKenzie 1997). Pyrite formed as a by-product of the sulfate-reducing process (Machel 2001). The occurrence of celestite is also considered to be related to $\mathrm{pH}$ changes during microbially mediated formation of dolomite (Rodri'guez-Aranda et al. 2005). So far, this mineral has been reported as a by-product of bacterial sulfate-reduction processes resulting in calcite (Taberner et al.

2002).

The arrangement of replacive dolomite in relation to gypsum outlines and beds (Figs. 6, 12) suggests that the lower horizons of the microbial mats in contact with gypsum probably represented a quite suitable environment for the activity of microbial communities (Gerdes et al. 2000; Rao et al. 2003). In this setting, anoxic conditions and availability of $\mathrm{SO}_{4}{ }^{22}$ related to gypsum dissolution could account significantly for microbial metabolic recycling of sulfur (Castanier et al. 1999). In addition, fast growth rates of gypsum contributed to enclose the microbial communities. The observed pattern of corrosion and replacement features points to strong boring activity of the microbes on and/or inside the gypsum crystals (Fig. 12), which fits well with an endoevaporitic nature of the microbial communities (Rothschild et al. 1994; Oren et al. 1995).

Gypsum dissolution processes release $\mathrm{Ca}$, and this usually accounts for the formation of calcite. Therefore, preferential gypsum replacement by dolomite instead of calcite is an unusual process that would require an additional source of $\mathrm{Mg}$ to increase the $\mathrm{Mg} / \mathrm{Ca}$ ratio in the solution. Commonly, the mechanism invoked to explain dolomite precipitation is 

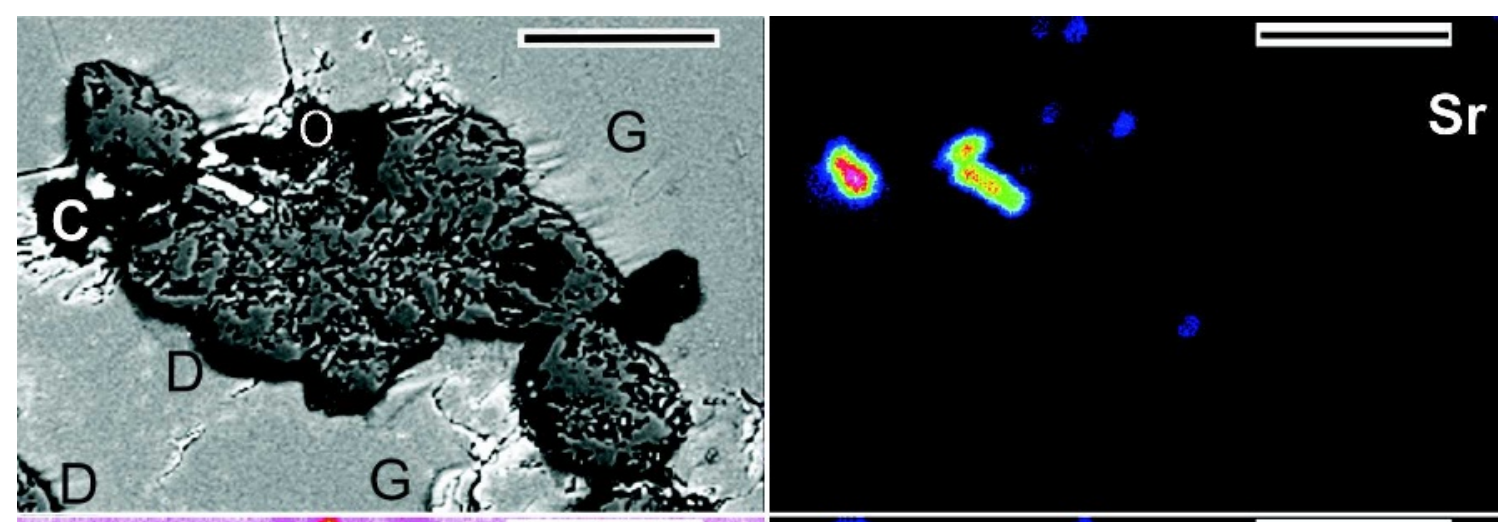

Sr Level

177

132
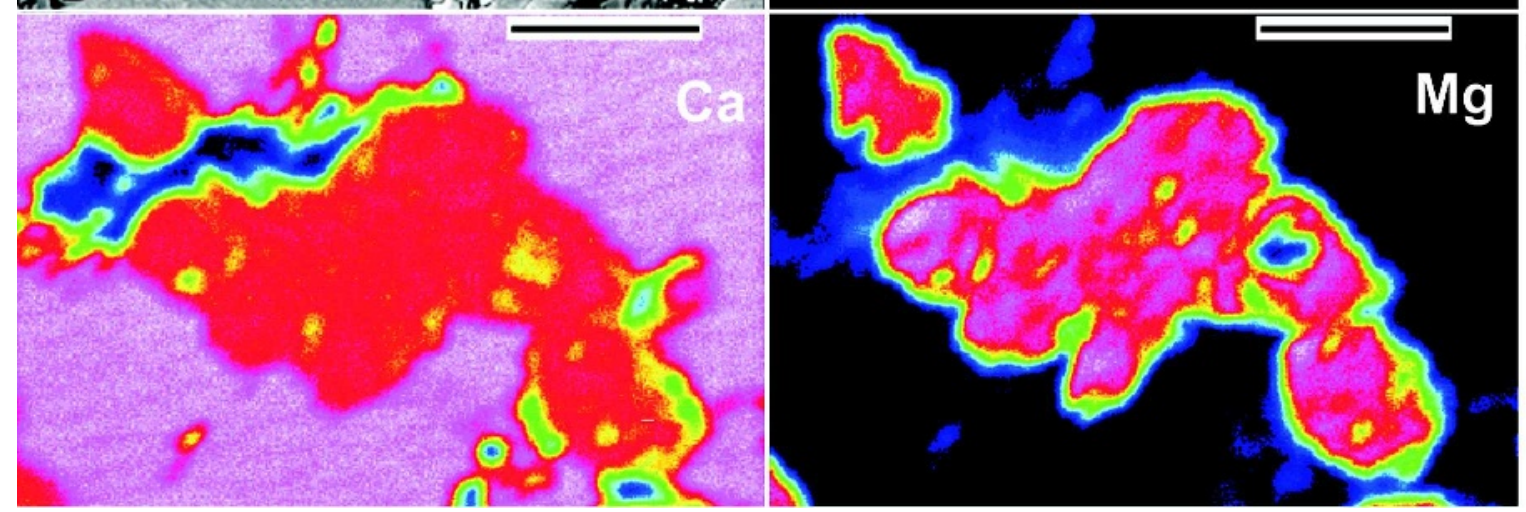

Ca Level

FIG. 13.-BSE image of porous spheroid dolomite crystals (D) replacing gypsum (G) and elemental mapping with the electron microprobe technique showing content variations of $\mathrm{Sr}, \mathrm{Ca}$, and $\mathrm{Mg}$. Note association of dolomite with celestite $(\mathrm{C})$, white minerals, and organic matter $(\mathrm{O})$, black areas. Organic matter, either surrounding or inside dolomite crystals, binds appreciable quantities of $\mathrm{Mg}$ and $\mathrm{Ca}$. Scale bar $520 \mathrm{~mm}$.

the evaporation of Mg-enriched waters (Pierre and Rouchy 1988). However, in the case study, negative $\mathrm{d}^{18} \mathrm{O}$ values in dolomite do not support this mechanism. In contrast, they indicate that the mineral precipitated from relatively diluted water that could be in relation with the aqueous film surrounding the microbial cells, as documented in modern sites (Noffke et al. 2003). In addition, negative $\mathrm{d}^{13} \mathrm{C}$ values (Table 1) reflect a significant organic-matter contribution in carbonate formation. The organic matter preserved in Miocene dolomite contains some $\mathrm{Mg}$ and Ca fixed on it (Fig. 13), which is consistent with the ability of the biofilms and EPS enveloping cyanobacterial mats to bind metals (Castanier et al. 1999). These features point out that bacteriolysis of cyanobacterial biomass promoted dolomite nucleation by increasing the concentration of $\mathrm{Mg}^{2+}$ released from decaying Mg-enriched cyanobacter-ial sheaths and exopolymers (Decho 1990). This model explains the preferential distribution of replacive dolomite in gypsum discontinuities.

\section{CONCLUSIONS}

The formation of dolomite in Miocene saline lake deposits (Christmas-tree gypsum unit) of the Madrid Basin was microbially mediated. The activity of bacterial communities was related mainly to microbial mats that developed in lake-margin areas and/or periods of relative dilution of lake water. Where dolomite beds are intercalated with gypsum, this mineral present as twinned selenite aggregates showing a specific "Christmas-tree" arrangement, the dolomite replaces both the underlying and overlying sulfate beds. A complex pattern of pitting, cleavage widening, cracking, and local detachment of gypsum subcrystals is recognized. The corrosion of gypsum was caused by the boring activity of endolithic microbes, presumably cyanobacteria, that were encased in the gypsum substrate (endoevaporite niches). As indicated by SEM imagery and fluorescence petrography, endoevaporitic microbial communities could maintain living activity, boring and partly corroding the gypsum substrate in which they were encased. Periodic pauses in the growth of the sulfate crystals favored microbial proliferation, allowing the corrosion of gypsum. Concomitantly, precipitation of dolomite mediated by the microbes resulted in progressive replacement of the gypsum.

\section{ACKNOWLEDGMENTS}

The work was supported by Projects BTE 2001-1443 and GR/AMB/0603/ 2004, financed by the Spanish Ministry of Science and Technology and the Educational Council of the Madrid Community, respectively. We thank Jean Marie Rouchy and an anonymous reviewer for critically reviewing the manuscript. In addition, Associate Editor Frances Westall and Editor Kitty Milliken provided valuable comments.

\section{REFERENCES}

Alonso-Zarza, A.M., and Calvo, J.P., 2002, Tajo Basin, in Gibbons, W., and Moreno, T., eds., The Geology of Spain: Geological Society of London, p. 315-320.

Arp, G., Thiel, V., Reimer, A., Michaelis, W., and Reitner, J., 1999, Biofilm exopolymers control microbialite formation at thermal springs discharging into the alkaline Pyramid Lake, Nevada, USA: Sedimentary Geology, v. 126, p. 159-176.

Arp, G., Reimer, A., And Reitner, J., 2003, Microbialite formation of increased alkalinity, Satonda Crater Lake, Indonesia: Journal of Sedimentary Research, v. 73 , p. $105-127$.

Ayllón-Quevedo, F., Souza-Egypsi, V., SAnz-Montero, M.E., and RodríguezAranda, J.P., 2005, Formation conditions of "Christmas tree" gypsum from the Madrid Basin (Spain): petrography and fluid inclusion analysis (abstracts): Abstracts of the $18^{\text {th }}$ Biennial Meeting of ECROFI (European Current Research on Fluid Inclusions).

Bathurst, R.G.C., 1975, Carbonate Sediments and Their Diagenesis: Amsterdam, Elsevier, Developments in Sedimentology, n. 12, 658 p.

Calvo, J.P., Ordóñez, S., García del Cura, M.A., Hoyos, M., and Alonso-Zarza, A.M., 1994, Madrid Basin (Miocene), in Gierlowski-Kordesch, E., and Kelts, K., eds., A Global Record of Lake Basins: Cambridge, Cambridge University Press, U.K., p. 303-305. 
Castanier, S., Métayer-Levrel, G., and Perthuisot, J.P., 1999, Ca-carbonates precipitation and limestone genesis - the microbiologist point of view: Sedimentary Geology, v. 126, p. 9-23.

Caumette, P., Matheron, R., Raymond, N., and Relexans, C., 1994, Microbial mats in the hypersaline ponds of Mediterranean salterns (Salins-de-Giraud, France) Federation of European Microbiological Societies, Microbiology Ecology, v. 13, p. $273-286$.

Cody, A.M., AND Cody, R.D., 1988, Gypsum nucleation and crystal morphology in analog saline terrestrial environments: Journal of Sedimentary Petrology, v. 58, p $247-255$.

Cody, A.M., AND CoDy, R.D., 1991, Chiral habit modifications of gypsum from epitaxial-like adsorption of stereospecific growth inhibitors: Journal of Crystal Growth, v. 113, p. 508-519.

Decho, A.W., 1990, Microbial exopolymer secretions in ocean environments: Their role(s) in foodwebs and marine processes: Annual Reviews of Oceanography and Marine Biology, v. 28, p. 73-154.

DedeCKKer, P., 1988, Biological and sedimentary facies of Australian salt lakes: Palaeogeography, Palaeoclimatology, Palaeoecology, v. 62, p. 237-270.

Douglas, S., AND YANG, H., 2002, Mineral biosignatures in evaporites: Presence of rosickyte in an endoevaporitic microbial community from Death Valley, California: Geology, v. 30, p. 1075-1078.

Eugster, H.P., And Hardie, L.A., 1978, Saline lakes, in Lerman, A., ed., Physics and Chemistry of Lakes: New York, Springer-Verlag, p. 237-293.

Folk, R.L., AND ChafeTz, H.S., 2000, Bacterially induced microscale and nanoscale carbonate precipitates, in Riding, R., and Awramik, S.M., eds., Microbial Sediments: Berlin, Springer-Verlag, p. 40-49.

Gerdes, G., HoltKamp, E.M., And Krumbein, W.E., 1985, Salinity and water activity related zonation of microbial communities and potential stromatolites of the Gavish Sabkha: Ecological Studies, v. 53, p. 238-266.

Gerdes, G., Dunajtschikpiewak, K., Riege, H., Taher, A., Krumbein, W., and REINECK, H., 1994, Structural diversity of biogenic carbonate particles in microbial mats: Sedimentology, v. 41, p. 1273-1294.

Gerdes, G., Krumbern, W.E., And NoffKe, N., 2000, Evaporite microbial sediments, in Riding, R., and Awramik, S., eds., Microbial Sediments: Berlin, Springer-Verlag, p. 196-208.

Goldsmith, J.R., and Graf, D.L., 1958, Relations between lattice constraints and composition of the $\mathrm{Ca}-\mathrm{Mg}$ carbonates: American Mineralogist, v. 43, p. 84-101.

Goldsmith, J.R., Graf, D.L., AND Heard, H.C., 1961, Lattice constants of the calciummagnesium carbonates: American Mineralogist, v. 46, p. 453-457.

Hardy, R.G., AND TuCKer, M.E., 1988, X-ray powder diffraction of sediments, in Tucker, M.E., ed., Techniques in Sedimentology: Oxford, U.K., Blackwell Science, p. 191-228.

Hughes, K.H., AND Lawley, B., 2003, A novel Antarctic microbial endolithic community within gypsum crusts: Environmental Microbiology, v. 5, p. 555-565.

KazmierczaK, J., AND KemPe, S., 2004, Microbialite formation in seawater of increased alkalinity, Satonda Crater Lake, Indonesia-Discussion: Journal of Sedimentary Research, v. 74, p. 314-317.

Kempe, S., and KazmierczaK, J., 1993, Satonda Crater Lake, Indonesia. Hydrogeochemistry and bicarbonates: Facies, v. 28, p. 1-32.

LAST, W.M., 1990, Lacustrine dolomite: An overview of modern, Holocene, and Pleistocene occurrences: Earth-Science Reviews, v. 27, p. 221-263.

MACHEL, H.G., 2001, Bacterial and thermochemical sulfate reduction in diagenetic setting-old and new insights: Sedimentary Geology, v. 140, p. 143-175.

Machel, H.G., Mason, R.A., Mariano, A.N., and Mucci, A., 1991, Causes and emission of luminiscence in calcite and dolomite, in Baker, C.E., and Kopp, O., eds., Luminiscence microscopy and Spectroscopy: qualitative and quantitative applications, SEPM, Short Course 25, p. 9-25.

McIntyre, I.G., Prufert-Debout, L., and Reid, R.P., 2000, The role of endolithic cyanobacteria in the formation of lithified laminae in Bahamian stromatolites: Sedimentology, v. 47, p. 915-921.

McKenzIE, J.A., 1991, The dolomite problem: An outstanding controversy, in Müller, D.W., McKenzie, J.A., and Weissert, H., eds., Controversies in Modern Geology: London, Academic Press, p. 35-54.

Noffke, N., Gerdes, G., And Klenke, T., 2003, Benthic cyanobacteria and their influence on the sedimentary dynamics of peritidal depositional systems (siliciclastic, evaporitic salty, and evaporitic carbonatic): Earth-Science Reviews, v. 62, p. 163-176.
Ogniben, L., 1954, La "Regola di Montura" de orientazione del gesso: Periodico di Mineralogia Annali, v. 23, p. 53-72.

Ordóñez, S., Calvo, J.P., Garcia del Cura, M.A., Alonso-Zarza, A.M., and Hoyos, M., 1991, Sedimentology of sodium sulphate deposits and special clays from the Tertiary Madrid Basin (Spain), in Anadon, P., Cabrera, L., and Kelts, K., eds. Lacustrine Facies Analysis, International Association of Sedimentologists, Specia Publication 13, p. 39-55.

Oren, A., KüHL, M., And Karsten, U., 1995, An endoevaporitic microbial mat within a gypsum crust: zonation of phototrophs, photopigments, and light penetration: Marine Ecology, Progress Series, v. 128, p. 151-159.

Pierre, C., AND Rouchy, J.M., 1988, Carbonate replacements after sulfate evaporites in the middle Miocene of Egypt: Journal of Sedimentary Petrology, v. 58, p. 446-456. Rao, V.P., Kessarkar, P.M., Krumbein, K.E., Krajewski, K.P., and Schneider, R.J., 2003. Microbial dolomite crust from the carbonate platform of Western India: Sedimentology, v. 50, p. 819-830.

Renaut, R.W., Jones, B., And Tiercelin, J.J., 1998, Rapid in situ silicification of microbes at Loburu hot springs, Lake Bogoria, Kenya rift Valley: Sedimentology, v. 45, p. $1083-1103$.

RodríGuez-Aranda, J.P., 1995, Sedimentología de los sistemas de llanura lutítica-lago salino del Mioceno de la zona oriental de la Cuenca de Madrid (Tarancón-Auñon) [Unpublished Ph. D. Thesis]: Complutense University, Madrid, $474 \mathrm{p}$.

Rodríguez-Aranda, J.P., Rouchy, J.M., Calvo, J.P., Ordóñez, S., and García del CurA, M.A., 1995, Unusual twinning features in large primary gypsum crystals formed in salt lake conditions, middle Miocene, Madrid Basin, Spain-palaeoenvironmental implications: Sedimentary Geology, v. 95, p. 123-132.

Rodríguez-Aranda, J.P., Sanz-Montero, M.E., Ayllón Quevedo, F., and SouzaEGYPSI, V., 2005, Formación de celestina dentro de un contexto microbiano en ambiente lacustre salino. Mioceno inferior de la Cuenca de Madrid: Macla, v. 3, p. $171-172$.

RothschiLd, L.J., 1990, Earth analogs for Martian life. Microbes in evaporites, a new model system for life on Mars: Icarus, v. 88, p. 246-260.

Rothschild, L.J., Giver, L.J., White, M.R., ANd ManCineldu, R.L., 1994, Metabolic activity of microorganisms in evaporites: Journal of Phycology, v. 30, p. 431-438

Rouchy, J.M., AND Monty, C., 2000, Gypsum microbial sediments: Neogene and modern examples, in Riding, R.E., and Awramik, S.M., eds., Microbial Sediments: Berlin, Springer-Verlag, p. 209-216.

Sanz-Montero, M.E., Rodríguez-Aranda, J.P., and Calvo, J.P., 2003, Dolomías primarias en ambiente lacustre salino: Mioceno de la Cuenca de Madrid: Geo-Temas, v. 5, p. 209-212.

Sanz-Montero, M.E., Rodríguez-Aranda, J.P., and Calvo, J.P., 2005, Biomineralization in relation with endoevaporitic microbial communities. Miocene lake deposits of the Madrid Basin, Central Spain: Geophysical Research Abstracts, v. 7, 06837.

SchreIBER, B.C., 1978, Environments of subaqueous gypsum deposition, in Dean, E., and Schreiber, B.C., eds., Marine Evaporites, SEPM, Short Course 4, p. 43-73.

Taberner, C., Marshall, J.D., Hendry, J.P., Pierre, C., and Thirlwall, M.F., 2002 Celestite formation, bacterial sulphate reduction and carbonate cementation of Eocene reefs and basinal sediments (Igualada, NE Spain): Sedimentology, v. 49, p. 171-190.

Vasconcelos, C., AND McKenzIE, J.A., 1997, Microbial mediation of modern dolomite precipitation and diagenesis under anoxic conditions (Lagoa Vermelha, Rio de Janerio, Brazil): Journal of Sedimentary Research, v. 67, p. 378-390.

Vasconcelos, C., McKenzie, J.A., Bernasconi, S., Grujic, D., and Tien, A.J., 1995, Microbial mediation as a possible mechanism for natural dolomite formation at low temperatures: Nature, v. 377, p. 220-222.

Warthmann, R., van Lith, Y., Vasconcelos, C., McKenzie, J.A., and Karpoff, A.M., 2000, Bacterially induced dolomite precipitation in anoxic culture experiments: Geology, v. 28, p. 1091-1094.

Wright, D.T., 1999, The role of sulphate-reducing bacteria and cyanobacteria in dolomite formation in distal ephemeral lakes of Coorong region, South Australia: Sedimentary Geology, v. 126, p. 147-157.

Wright, D.T., AND WACEY, D., 2005, Precipitation of dolomite using sulphate-reducing bacteria from the Coorong Region, South Australia: significance and applications: Sedimentology, v. 52, p. 987-1008 